\title{
Approaches from a regional perspective of the insurance evolution in Romania - digitization of viable solution for the development of this sector during the pandemic
}

\author{
Maria Ciurea* \\ Department of Economics Sciences, University of Petrosani, Petrosani, Romania
}

\begin{abstract}
Romania's regional policy encourages the harmonious development of the territory, allowing all regions to fully capitalize on their advantages and opportunities in their economic and social development, whose main objective is to reduce disparities between regions and ensure a balanced level of development. Through this study, a synthesized analysis is performed on the evolution of the Romanian insurance market in terms of gross written premiums from general and life insurance by development regions and where the important contribution of this sector to the growth of GDP The main finding highlights the fact that the development region Bucharest - Ilfov, holds over $44 \%$ of the regional insurance market and has a substantial contribution to economic growth. At the same time, aspects of digitalization perceived as a viable solution for the dynamics of this sector during the current pandemic are also targeted.
\end{abstract}

\section{Introduction}

The growth and diversification of economic activity and implicitly of the international exchanges of values have led to the growth and development of active and competing insurance and reinsurance markets which are marked by a high degree of heterogeneity determined by the existence of a great diversity of business types and categories. In the market economy, insurance is a sector of benefits of the natural economy of each country that contributes to the protection of goods and persons against the various risks taken in insurance. At the same time, this sector has an important role to play in increasing gross domestic product and investment placements [1].

At present, the macroeconomic climate is extremely favourable for the development of the insurance industry. The positive trend will continue in the future by stimulating the growth of demand for insurance products, and the introduction of tax incentives and other types of compulsory insurance should guarantee the insurance industry consistent growth rates in the coming years.

\footnotetext{
* Corresponding author: mariamacris2011@yahoo.com
} 
For a country like Romania, in the middle of a wide, deep and complex process of transformation in economic, financial, social and political terms, the establishment of precise strategic objectives in the field of insurance, to which everyone's efforts should be focused, as well as the exact knowledge of the steps that must be taken in order to achieve these objectives have become essential steps in the evolution of this field. In our country, in recent years, there have been significant changes in the insurance market, identified by: increasing the number of operators in the market; increase turnover in insurance and reinsurance companies; increasing the call for insurance protection: intensifying competition between insurance companies, put in the situation of adapting their insurance offer to the demands and possibilities of customers; the low level of financial capacity to insure the population and even other state and private entities; the evolution of the national insurance market towards another type of monopoly, namely of multinational companies, becoming largely a captive market [2].

The high degree of concentration on the insurance market is a vulnerability both in terms of exposure by insurance classes and in terms of significant market shares held by a relatively small number of insurance companies. From the perspective of exposure by classes, the Romanian insurance market is characterized by a high degree of concentration both for the general insurance segment, where the dominance of car insurance in the local market persists, as well as in terms of life insurance activity. The local market's dependence on car insurance has led to losses for insurance companies over time. In this regard, in order to reduce the dependence of the insurance market on car insurance, the Financial Supervision Authority has developed a series of financial education programs in order to diversify the interest of Romanian consumers for a wider variety of insurance products and services, working groups aimed at developing agricultural and health insurance markets.

Considering this, there is a tendency to diversify consumer interest in health insurance products, which implicitly leads to the development of these insurance segments. In the long run, the development of the health insurance market can improve the profitability of insurance companies by reducing dependence on insurance that brings higher losses, which will lead to ensuring the financial stability of the entire insurance market in Romania [3, 4$]$.

Therefore, ensuring the balanced and sustainable economic growth and social development of some geographical areas constituted in development regions, improving Romania's international competitiveness, as well as reducing the economic and social gaps between our country and the Member States of the European Union were grounds on which, in 1998, were created, through the voluntary association between the neighbouring counties, the Economic Development Regions of Romania. Although they are entities without administrative power and legal personality, their role is mainly aimed at coordinating and managing regional development projects, respectively the absorption of funds from the European Union [5, 6].

Regarding the presented aspects, this study captures the evolution of the Romanian insurance market on each development region, as well as the significant contribution of this sector to the growth of the gross domestic product of the country. We must also not forget that the current period is strongly marked by the coronavirus pandemic and its effects on the insurance sector.

\section{Research methodology}

The economic development of the regions determines decisively the general levels of their development and implicitly the dynamics on the insurance market. To carry out this paper, we used a systemic approach to the information resulting from the synthesis and systematization of theoretical ideas regarding the insurance market in general and Romania in particular, in terms of its regional evolution, and the phenomenon of digitization as a 
solution for its dynamics in the insurance sector during the pandemic. In order to obtain theoretical information, we studied various articles and specialized studies in the field of insurance found in books, magazines or proceedings of national or international conferences. The analysis of statistical data was performed based on information taken from the websites of the National Institute of Economic Statistics (I.N.S.E.), the Financial Supervision Authority (A.S.F.) and various Insurance and Reinsurance Companies in Romania.

\section{Results and discussions}

\subsection{Aspects of the insurance evolution by development regions}

The nomenclature of Territorial Units for Statistics, known under the abbreviation of NUTS, has been applied since 1998 and is structured in: macro-regions, regions and counties to which the city of Bucharest is attached. Therefore, at the level of Romania we find:

- 4 macro-regions: Macro-region 1, 2, 3 and 4 which have the abbreviation NUTS I;

- 8 development regions, with the abbreviation NUTS II;

- 42 counties, with the abbreviation NUTS III.

These abbreviations are a nomenclature in line with European Union (EU) practice. In the composition of macro-regions we find:

- macro-region 1: North - West Region and Centre Region;

- macro-region 2: North-East Region and South-East Region;

- macro-region 3: South - Muntenia Region and Bucharest - Ilfov Region;

- macro-region 4: South-West Oltenia Region and West Region.

The eight development regions resulting from the association of county councils for regional development are simple statistical measures given that they have no legal personality and therefore have no administrative or legislative leadership.The role of these development regions is found in the field of allocating EU funds for regional development and regional statistics, as well as in coordinating regional infrastructure projects with the accession to the Committee of the Regions after Romania's entry into the EU [7].

The development regions comprise between 2 and 7 counties and the name assigned to each corresponds to the geographical position in which they are located. The structure by counties of these regions is presented in table 1 .

Table 1. The component counties of the development regions in Romania.

\begin{tabular}{|c|l|c|l|}
\hline $\begin{array}{c}\text { No. } \\
\text { crt. }\end{array}$ & Name of the region & $\begin{array}{c}\text { Number } \\
\text { of } \\
\text { counties }\end{array}$ & \multicolumn{1}{|c|}{ Component counties } \\
\hline 1 & $\begin{array}{l}\text { Bucharest - Ilfov } \\
\text { Region }\end{array}$ & 2 & Bucuresti (B) and Ilfov (IF) \\
\hline 2 & North - West Region & 6 & $\begin{array}{l}\text { Bihor (BH), Bistrita-Nasaud (BN), Cluj (CJ), Salaj (SJ), } \\
\text { Satu -Mare (SM), Maramures (MM) }\end{array}$ \\
\hline 3 & $\begin{array}{l}\text { South - Muntenia } \\
\text { Region }\end{array}$ & 7 & $\begin{array}{l}\text { Arges (AG), Calarasi (CL), Dambovita (DB), Teleorman } \\
\text { (TR), Giurgiu (GR), Ialomita (IL), Prahova (PH) }\end{array}$ \\
\hline 4 & South-East Region & 6 & $\begin{array}{l}\text { Braila (BR), Buzau (BZ), Constanta (CT), Galati (GL) } \\
\text { Vrancea (VR), Tulcea (TL) }\end{array}$ \\
\hline 5 & Centre Region & 6 & $\begin{array}{l}\text { Alba (AB), Brasov (BV), Covasna (CV), Harghita (HR), } \\
\text { Mures (MS), Sibiu (SB) }\end{array}$ \\
\hline 6 & North-East Region & 6 & $\begin{array}{l}\text { Bacau (BC), Botosani (BT), Iasi (IS), Neamt (NT), } \\
\text { Suceava (SV), Vaslui (VS) }\end{array}$ \\
\hline 7 & West Region & 4 & $\begin{array}{l}\text { Arad (AR), Caras-Severin (CS), Hunedoara (HD), Timis } \\
\text { (TM) }\end{array}$ \\
\hline 8 & $\begin{array}{l}\text { South-West Oltenia } \\
\text { Region }\end{array}$ & 5 & $\begin{array}{l}\text { Dolj (DJ), Gorj (GJ), Mehedinti (MH), Olt (OT), Valcea } \\
\text { (VL) }\end{array}$ \\
\hline 9 & Total & 42 & \\
\hline
\end{tabular}


The development regions seen through the prism of insurance are differentiated by their level of concentration. If until 2005 there was a tendency of intensive exploitation of the geographical area, especially in Bucharest and in large urban centres, which contributed to the increase of the level of insurance Herfindahl Gini-Strück, Herfindahl Gini-Strück loans, after 2005, until in 2008, the insurance trend was increasing, and starting with 2008 the insurance dynamics changed, reaching in 2019 a cumulative gross total of gross written premiums of 10.9 billion lei, which represents an increase of $14.57 \%$ compared to 2016 , and their arrangement by geographical regions is presented in table no.2.

Table 2. Comparative situation for the years 2016 - 2019 regarding the distribution Gross Subscribed Premiums (P.B.S.) by development regions.

\begin{tabular}{|c|c|c|c|c|c|c|c|}
\hline \multirow{3}{*}{$\begin{array}{c}\text { Develop- } \\
\text { ment } \\
\text { region }\end{array}$} & \multirow{3}{*}{$\begin{array}{c}\text { Total P.B.S. } \\
2016\end{array}$} & \multirow{3}{*}{$\begin{array}{c}\text { Total P.B.S. } \\
2019\end{array}$} & \multirow{3}{*}{$\begin{array}{c}\% \\
\text { out } \\
\text { of } \\
\text { the } \\
\text { total } \\
2019 \\
\end{array}$} & \multicolumn{4}{|c|}{ from which: } \\
\hline & & & & \multicolumn{2}{|c|}{ General insurance } & \multicolumn{2}{|c|}{ Life insurance } \\
\hline & & & & RON & $\%$ & RON & $\%$ \\
\hline $\begin{array}{l}\text { Bucureşti } \\
\text {-Ilfov }\end{array}$ & $3,905,722,296$ & $4,856,380,358$ & 44.23 & $3,694,119,403$ & 42.34 & $1,162,260,955$ & 51.52 \\
\hline $\begin{array}{l}\text { North - } \\
\text { West }\end{array}$ & $1,064,154,540$ & $1,112,013,301$ & 10.13 & $887,321,548$ & 10.17 & $224,691,753$ & 9.96 \\
\hline South & $870,721,532$ & $967,091,317$ & 8.81 & $817,522,409$ & 9.37 & $149,568,908$ & 6.63 \\
\hline $\begin{array}{l}\text { South - } \\
\text { Est }\end{array}$ & $798,190,196$ & $923,782,111$ & 8.41 & $771,280,480$ & 8.84 & $152,501,631$ & 6.76 \\
\hline Center & $871,280,708$ & $903,470,003$ & 8.23 & $732,018,465$ & 8.39 & $171,451,538$ & 7.60 \\
\hline $\begin{array}{l}\text { North - } \\
\text { Est }\end{array}$ & $762,098,653$ & $877,464,025$ & 7.99 & $720,676,105$ & 8.26 & $156,787,920$ & 6.95 \\
\hline West & $652,126,721$ & $754,038,125$ & 6.87 & $602,890,058$ & 6.91 & $151,148,067$ & 6.70 \\
\hline $\begin{array}{l}\text { South - } \\
\text { West }\end{array}$ & $463,044,077$ & $585,721,873$ & 5.33 & $498,191,351$ & 5.71 & $87,530,522$ & 3.88 \\
\hline Total & $9,380,935,173$ & $10,980,833,602$ & 100 & $8,724,892,308$ & 100 & $2,255,941,294$ & 100 \\
\hline
\end{tabular}

Source: author processing after A.S.F., The evolution of the insurance market in 2016 and 2019 [8]

From the comparative analysis by components in 2016-2019, a series of aspects can be deduced regarding the absolute value of the Gross Subscribed Premiums (P.B.S.) on the development regions and their dynamics, with the highlighting of some factors that make their mark on their dispersion.

The development region Bucharest - Ilfov, the strongest region of the country, as can be seen, it is the core of the insurance market in our country. The characteristic of this area is given by the practice of various forms of insurance, by the competition it makes to the other regions and by the availability of insurance institutions towards the permanent purchase of new insurance products.

It should be noted at the level of the Bucharest-Ilfov Region that, being the largest urban agglomeration of the country and the insurance density is the highest, respectively $42.34 \%$ of the general insurances and $51.52 \%$ of the life insurances at the level of 2019. Therefore, in the Bucharest-Ilfov Region, the share of insurance is more than significant, within which $44.23 \%$ of the business takes place on average. The year-on-year percentage increase in gross written premiums contributed to the formation of regional GDP, a context in which the Bucharest-Ilfov Region remains the largest contributor with $26.96 \%$ to the formation of Romania's GDP, according to available statistics at the level of 2018 [9].

Characterized by the Bucharest - Ilfov region with the highest percentage of underwriting of gross insurance premiums, $11.34 \%$ in 2016 and $10.13 \%$ in 2019, the North - West Region does not represent a uniformity in its territorial development. The counties located in the south and west of the region: Cluj, Bihor and Satu Mare, have a stronger industry which makes them more economically stable, however, the counties: Bistriţa-Năsăud, Maramureş 
and Sălaj are poorer and hence neither the distribution of PBS it is not uniform within the region.

Although the territorial development is not uniform, the economic activity is facilitated by the crossing of the region by 6 European roads, by the Transylvania Highway and by the existence of 4 airports. The geographical position, close to Western Europe and the existing infrastructure explain the attraction of foreign investors and the region's contribution to the formation of Romania's GDP of $12.05 \%$ in 2018.

Returning to the insurance sector, we note that the North-West Region is in the ranking of regions in 2019 with a percentage of $10.17 \%$ of P.B.S. for non-life insurance and $9.96 \%$ for life insurance.

The South - Muntenia Region has been in permanent development since 1996, and in 2016 it had a spectacular increase of $31.87 \%$ compared to 2014. In 2019, P.B.S. presented the following situation: $9.37 \%$ general insurance and $6.63 \%$ life insurance. Paradoxically, it is the fact that it has the largest number of counties in its composition and due to the two strong more industrialized counties: Argeş and Prahova, the regional GDP contributes with $11.79 \%$ to the formation of Romania's GDP.

The South-East Region, the second region in area, with an interesting relief that concentrates almost all forms and in which cities concentrate $55.5 \%$ of the population, is characterized by an uneven development, the regional GDP contributing $11,27 \%$ of Romania's GDP. In 2019, P.B.S decreased slightly from $8.41 \%$ to $8.50 \%$ in 2016 , the insurance market developing differently within the component counties. However, the distribution of P.B.S. on the insurance market components it is quite balanced (general insurance $8.84 \%$ and life insurance $6.76 \%$ ).

The Central Region, although in this region the industrial branch is predominant, especially in the counties of Braşov and Sibiu, also has a service sector that brings an important contribution to the development of the local economy. It should be noted that the insurance sector registered a slight decrease in 2019 from $8.23 \%$ of the total gross written premiums of insurance, compared to $9.28 \%$ in 2016 . Although ethnically varied, the Region Centre in terms of PBS for general insurance it registered $8.39 \%$ and for life insurance $7.60 \%$ in 2019, but also for the contribution of the insurance sector to the formation of the regional GDP found in proportion of $11.39 \%$ in Romania's GDP.

The North-East Region is not among the poorest of the eight development regions, but is characterized by the existence of human resources and concerns in the field of tourism, agriculture and industry which creates the premises for raising living standards and developing the insurance sector. Although the regional GDP contributes to Romania's GDP by $10.38 \%$, in the European context the North-East Region is among the 19 European regions that register a GDP / capita below the European average of 50\% (34\%), perpetuating since 2011 [10]. However, the North-East region is distinguished by an underwriting of PBS which fell slightly from $8.12 \%$ in 2016 to $7.99 \%$ in 2019 and a underwriting of the general insurances of $8.26 \%$ and of the life insurances of $6.95 \%$ in 2019 .

The last two development regions of the country are in the last places, but they have an insurance market adequate to the development of the regional economy.

The West Region presents a socio-economic development based on labour force, highly specialized and which contributes to the achievement of a regional GDP which is found in a proportion of $9.39 \%$ in Romania's GDP. However, it is observed that the distribution of P.B.S on the insurance market components is quite balanced for the general insurances of $6.91 \%$, compared to P.B.S. for life insurance of $6.70 \%$ in 2019 . Cumulatively, within the Western Region, P.B.S evolved almost insignificantly, from $6.95 \%$ in 2016 to $6.87 \%$ in 2019.

The South - West Oltenia Region is the poorest development region of the country, with a regional GDP that is found in Romania's GDP in proportion of $7.70 \%$. This is a consequence of the fact that before 1990 agriculture predominated, which gradually diluted, 
and the existing industry was destroyed, currently there are two operational industrial parks, located in Dolj County (Craiova) and Gorj County (Sadu), and a Greenfield industrial park, the Corabia. To such a state of affairs is added the lack of large foreign investors, except for the FORD Car Factory, which is also reflected in the insurance sector. The Southwest Oltenia Region made the "great evolution" from 4.93\% P.B.S. in 2016, at 5.33\% in 2019, with a subscription between the two components of the insurance market of $5.71 \%$ for non-life insurance and $3.88 \%$ for life insurance in 2019 , which places it on last place in the national hierarchy in the field of insurance.

Despite all the disparities identified in the development regions presented until 2019, the Romanian insurance market in 2020 remained oriented towards the general insurance activity, which held a share of $81 \%$ of the total gross premiums written by insurance companies authorized and regulated by the FSA Increasing the share of gross written premiums for non-life insurance in the total volume of P.B.S. by companies authorized and regulated by the A.S.F. in 2020, compared to 2019, it took place against the background of P.B.S. for the general insurance activity by $6.3 \%$, at the same time with a slight decrease of the value of the underwriting for the life insurance activity by $1.6 \%$. It should also be noted that the non-life insurance market remained dominated by motor insurance and motor third party liability insurance, including carrier liability, accounting for approximately $71 \%$ of total gross written premiums for insurance business and $57 \%$ of total gross written premiums of insurance companies in 2020 [11].

Although the life insurance segment registered a slight decrease compared to 2019, compared to 2016-2018, the volume of gross written premiums continued to be higher, exceeding the level of 2.2 billion lei in 2020 , which was supported by a $1.6 \%$ increase in life insurance, annuities and supplementary life insurance underwriting, which accounts for about $65 \%$ of total life insurance underwriting. At the same time, health insurance continued to register positive developments in 2020, with an increase of $18 \%$ compared to 2019 , increasing its share in total gross written premiums to $3.9 \%$, from $3.5 \%$ in 2019 .

The current context has been severely affected by the increased uncertainties regarding the future dynamics of economic activities, amplified by the negative effects of the COVID19 pandemic, has generated increasing interest for collateral insurance which recorded a volume of gross premiums written in 2020, of $68 \%$ compared to 2019 . All this having a positive impact on the diversification of insurance segments on the market.

\subsection{Digitization as a solution for the pandemic in the evolution of the Romanian insurance market}

In the context of the COVID-19 pandemic and the effects of necessary measures imposed by states to prevent the spread, the socio-economic impact is major, the latest data indicating the entry of the global economy in the most significant recession since the Great Depression. The latest estimates from the International Monetary Fund (IMF), published in 2020, indicate a negative economic growth of $3 \%$ this year, well below the level of 2009 , reached during the global financial crisis, when the global economy contracted with $0.1 \%$.

In the first quarter of 2020 , no one imagined that it was so close when insurance would become easily accessible in the digital environment, anytime and anywhere, although the digitization processes were already initiated by companies, but the COVID-19 pandemic it visibly accelerated this process and it turned out that what could have been achieved in a few years was available in just a few months [12].

The Romanian insurance market has quickly adapted to the new context, applying telework solutions for employees and digital solutions for customers, through which insurers' services can be accessed - acquisition, payment of premiums, notification and finding of damages and payment of compensation. Thus, an accelerated digitization has taken place, 
which is one of the opportunities of this pandemic and which is a positive aspect of such a situation.

Insurance companies have taken various steps lately, both to support customers by possibly postponing the payment of premiums and by including the risk of COVID-19, although the pandemic was excluded from any insurance policy. They have done and continue to do everything possible to help their customers in difficulty during this period, supporting the restart of the Romanian economy. Therefore, insurers renegotiated contracts with customers, rescheduled premiums and granted grace periods, included the risk of COVID-19 in life and health insurance, thus demonstrating flexibility and attention to customer needs. Insurance companies will continue to implement everything they set out to do, as they are all part of a mechanism and together with other actors can help the economy regain its true value.

Following the adaptation to the new conditions imposed by the authorities, all companies had to implement, in a very short period of time, digital methods and solutions that could support both the company's activity and the protection of employees and customers. By adapting to the rules of social distance, all activities were successfully carried out remotely, thus registering a significant increase in the use of electronic payment instruments by customers [13]. Therefore, the sustained trend of digitization of the entire compensation process has contributed to the reduction of the liquidation times of the RCA and Casco files. All stages, starting with online notification, continuing with self-finding, electronic transmission of all documents and acceptance by electronic signature and direct payment of compensation, worked very well during the pandemic when the state of emergency was imposed.

Before entering this pandemic crisis, the Romanian MTPL insurance market was characterized by an unsustainable and much higher damage rate than in other European markets. It is true that during the state of emergency the volume of damages was reduced, but this aspect will help the market to bring the damage rate to a normal level only in the short term, without solving the problems existing at that time, in the long term. In addition to the series of negative aspects triggered by the pandemic, there have been and are segments of the insurance market that have evolved extremely well in such a period. It is noteworthy that, although it was a complicated period, the insurance market behaved quite well, in terms of the current context generated by the COVID-19 pandemic. It also shows that this market has great potential in its significant contribution to the increase of gross domestic product, as evidenced by statistics showing that in 2020, the share of the insurance market in Gross Domestic Product was about $2.3 \%$, and Romanian insurance companies subscribed gross premiums amounting to approximately 11.5 billion lei, increasing by approximately $4.6 \%$ compared to the value recorded in 2019. Also, this positive evolution of this sector was possible also due to the increase in the area of health insurance, where sales increased by $34 \%$ and those in the area of home insurance, which offset the insurance segments with negative evolution of this period [14].

Insurance and digitalisation are two intertwined areas. Digitization is part of everyone's life, and insurance has the role of protecting us financially from risks. At the same time, digitalization can effectively develop the insurance market, which must grow healthily, with new products and services to meet the needs of its customers, to protect them and for the stability of insurance companies.

\section{Conclusions}

European regional development policy aims to turn problems into opportunities and is based on the political principle that richer countries and regions must stand in solidarity with the poorest. At the same time, the economic principle is promoted that lower production levels 
in the Member States and poorer regions can be a loss of potential and can be an opportunity for the development of the European Union, as investment in modern infrastructure and innovative business is considered an education. Better quality and human resources training in less developed regions are new opportunities and added value, thus expanding the economic potential of all Member States. In this respect, regional development requires effective cooperation and interrelationships between public authorities, economic agents and social groups at all levels. Thus, Romania's regional development will continue in the programming period 2021-2027, where it will benefit from funds especially for the first Policy Objective: A smarter Europe, by promoting an innovative and intelligent economic transformation.

Starting from the aspects presented during this paper, it can be appreciated that the prospects for economic growth that will be reflected through the GDP, as well as individual income, will be favourable factors that will make a major contribution to insurance growth. Swiss Re Insurance Group of Switzerland appreciates that globally, the economy will continue to grow and, in particular, emerging markets will grow strongly, which will also attract increased insurance premiums in all regions of the world, especially in the general insurance segment. However, the estimated trend at the level of the global insurance market will not be uniform, there will certainly be different manifestations generated by the local contexts, as well as by the specific situations at the level of each development region. At the level of the Romanian insurance market, which is in full maturity and dominated by the classic distribution channels of insurance products, it is difficult to establish the trends that can be identified, especially in terms of telematics technology.

Digital technology has also revolutionized the insurance industry, and the Internet, mobile devices and telematics have radically changed customer interaction. Therefore, they will have greater access to information to assess risk exposures and find out for themselves how they can cover their need for insurance. Therefore, digitization aims to bring us a better life and insurance to protect it. Insurance products must be for everyone, at the same quality level, and insurers can benefit digitally internally to become more efficient, insurance products to be cheaper, closer to people's needs, regardless of the form of distribution or methods of compensation, classic or digital. Therefore, digitalization is a constantly evolving and transforming phenomenon that must be channelled so that the opportunities it develops are in favour of people, consumers of financial services. For this reason, the supervisory authority, financial market actors, private companies in related fields, such as IT or IT security, must work together, discuss and identify the best solutions for the Romanian insurance market.

\section{References}

1. M. Simionescu, Scientific Journal Economics, Management and Sustainability, 4(1), 21 (2019)

2. M. Măcriş, Bazele economiei (Universitas, 2013)

3. C. Mare, S. L. Dragos, I.M. Dragota, G.M. Muresan, C.A. Urean, Spatial convergence processes on the European Union's life insurance market, Economic Computation and Economic Cybernetics Studies and Research, 50(4), 93 (2016)

4. M. Ciurea, C. Ioanăş, Theoretical and Evolutionary Approaches in the Current European Context, Proceedings of 34th International Business Information Management Association Conference, 9233 (2019)

5. S. L. Dragos, Economic Research - Ekonomska Istraživanja 27(1), 169 (2014)

6. S. L. Dragos, C. Mare, I. M. Dragota, C. M. Dragos, G. M. Muresan, Economic Research-Ekonomska Istraživanja 30(1), 1477 (2017) 
7. E. Nica, V. Sima, I. Gheorghe, A. Drugau - Constantin, C.O. Mirica (Dumitrescu), Sustainability 10(10), 3450 (2018)

8. ASF Romania, The evolution of the insurance market in 2019_Raport, https://asfromania.ro/files/analize/Evolutia\%20pietei\%20asigurarilor\%20in\%202019_r epost\%20_08042020.pdf

9. National Institute of Statistics of Romania, tempo-online database, http://statistici.insse.ro:8077/tempo-online/\#/pages/tables/insse-table

10. M. Ciurea, M. Man, Considerations Regarding the Influence of Insurance on the Economic Growth in Romania, Proceedings of the International Business Information Management Conference (35th IBIMA), 16.267 (2020)

11. ASF Romania, The evolution of the insurance market in 2020_Raport, https://asfromania.ro/files/analize/Evolutia\%20pietei\%20asigurarilor\%202020_202103 18_site24032021.pdf

12. PRIMM Insurance \& Pensions Review, Asigurari, Pandemie, Economie - Solutii inteligente nascute de criza, Bucharest: Media XPRIMM Romania, https://www.primm.ro/asigurari--pandemie--economie---prima-conferinta-online-apietei-asigurarilor-din-romania_2356.html

13. M. Ciurea, Proceedings of the Ist International Scientific and Practical Conference on Digital Economy (ISCDE) 105, 539 (2019)

14. PRIMM Insurance \& Pensions Review, Cum schimbă pandemia viitorul asigurărilor, Bucharest: Media XPRIMM Romania, https://www.primm.ro/arhiva/web_2_2020.pdf 